\title{
PENGARUH WORD OF MOUTH TERHADAP KEPUTUSAN PEMBELIAN KONSUMEN PADA USAHA MIE AYAM PAK AGUS DI KOTA BATU
}

\author{
Yuda Oktavianto \\ PT. Surya Madistrindo \\ E-mail: yudhaoktavianto@yahoo.com
}

\begin{abstract}
The research objective was to determine the influence of communication Word Of Mouth (WOM) on consumer purchasing decisions at Pak Agus chicken noodle products in Batu city. The method used was a survey. The dependent variable was purchase decision and the independent variable was Word of Mouth Communication. Respondents were consumers who make repeat purchases in chicken noodle Pak Agus least three times, as many as 100 people. Sampling technique used purposive sampling. Data collection was using questionnaires. Analysis tool used was a simple linear regression. The results showed the positive influential among variables Word Of Mouth (WOM) on Purchase Decision which was supported by $77.2 \%$ contribution. It meant that all consumers who buy chicken noodle were $77.2 \%$ influenced by the communication word of mouth.
\end{abstract}

Keywords: Communication, Word of Mouth, Purchase Decision

\section{PENDAHULUAN}

Komunikasi pemasaran merupakan proses yang dilakukan oleh perusahaan dalam mengkoordinasikan beberapa elemen promosi dan kegiatan pemasaran lainnya sehingga terjalin komunikasi dengan konsumen perusahaan (Belch \& Belch, 2004). Konsep yang secara umum sering digunakan untuk menyampaikan pesan adalah apa yang disebut bauran promosi (promotional mix) disebut bauran promosi karena biasanya pemasar sering menggunakan jenis promosi yang terintergrasi dalam suatu rencana promosi produk. Terdapat lima jenis promosi yang biasa disebut sebagai bauran promosi yaitu iklan (advertising), penjulan tatap muka (personal selling), promosi penjualan (sales promotion), hubungan masyarakat dan publisitas (publlic and publlic relation)serta pemasaran langsung (direct marketing) (Kotler, 2000). Untuk mendukung suatu bauran pemasaran mencapai tujuan komunikasi pemasaran, pemasar harus benar-benar memikirkan pesan komunikasi pemasaran dan media komunikasi pemasaran untuk menyampaikan pesan tersebut.

Menurut Hoskins(2007) dilihat dari sifatnya salah satusifat komunikasi word of mouth communicationatau komunikasi mulut ke mulut, komunikasi ini dibutuhkan untuk kepentingan internal dan eksternal organisasi. Komunikasi untuk kepentingan internal adalah sebagai alat koordinasi, mengontrol, setiap kegiatan atau aktivitas dalam organisasi baik individu maupun secara bersama ditingkat manajemen dan level staf karyawan. Komunikasi pemasaran word of mouth terasa mendominasi dalam suatu usaha/bisnis karena merupakan suatu komunikasi pemasaran yang tidak mempergunakan biaya besar seperti halnya iklan. Hal tersebut dikarenakan komunikasi pemasaran tergantung pada penyebaran informasi dari seseorang kepada yang lain. Dalam hal ini, cerita positif antara seorang konsumen ke calon kon- 
sumen lainnya menjadi kekuatan bagi komunikasi word of mouth yang secara dominan dipergunakan oleh para usahawan maupun pebisnis tersebut. Kehadiran WOM dalam mengembangkan kegiatan komunikasi dalam bisnis tidak akan membunuh kegiatan komunikasi pemasaran lainnya, tetapi bisa dijadikan sebagai salah satu alternatif dari bauran promosi sehingga menghasilkan komunikasi pemasaran yang lebih efektif dan menjual. Yang perlu untuk diingat adalah WOM akan menghasilkan sesuatu yang positifjika produk yang dibeli menghasilkan kepuasan pada konsumennya. Ini akan menimbulkan image positif bagi konsumen dan tanpa diarahkan akan mengatakan hal tersebut kemana saja, dimana saja dan kapan saja. Sebaliknya, akan menjadi musuh yang menyerang kitajika produk yang dikonsumsi konsumen mengecewakan.

Menurut Brown et al (2005) word of mouth terjadi ketika konsumen berbicara kepada orang lain mengenai pendapatnya tentang suatu merek, produk, layanan atau perusahaan tertentu pada orang lain. Apabila konsumen menyebarkan opininya mengenai kebaikan produk maka disebut sebagai positif WOM, tetapi bila konsumen menyebarluaskan opininya mengenai keburukan produk maka disebut sebagai negatif WOM. Positif WOM dapat berarti apabila seseorang melakukan bisnis dengan suatu perusahaan dan melakukan rekomendasi kepada orang lain mengenai perusahaan tersebut dan memuji kualitas perusahaan tersebut.

WOM saat ini menjadi bagian penting dalam studi pemasaran mengingat bahwa komunikasi dalam WOM mampu mempengaruhi keputusan pembelian konsumen.Konsumen lebih mempercayai Word of Mouth dalam menilai sebuah produk, dan mempengaruhi keputusan pembelian mereka dibandingkan iklan. Cerita dan pengalaman seseorang menggunakan sebuah produk terdengar lebih menarik yang bisa mempengaruhi pendengarnya untuk ikut mencoba produk tersebut. Di sisi lain, kekuatan WOM juga bertambah mengingat bahwa manusia adalah makhluk sosial yang senang berinteraksi dan berbagi dengan sesamanya, termasuk masalah preferensi pembelian. WOM mampu menyebar begitu cepat bila individu yang menyebar- kannya juga memiliki jaringan yang luas. WOM adalah suatu sarana komunikasi pemasaran yang efektif, murah, dan kredibel (Kertajaya, 2007).

Usaha berskala kecil dapat dikatakan sebagai salah satu solusi masyarakat untuk tetap bertahan untuk menghadapi krisis melalui pelibatan diri dalam aktivitas ekonomi terutama usaha yang berkarakteristik informal. Menurunnya pendapatan masyarakat tentu saja dapat mengurangi daya beli terhadap produk-produk yang sebelumnya banyak disuplai oleh usaha berskala besar. Bukan tidak mungkin produk-produk industri kecil justru menjadi substitusi bagi produk-produk usaha besar yang mengalami kebangkrutan atau setidaknya masa-masa sulit akibat krisis ekonomi. Dengan demikian kecenderungan tersebut merupakan respon terhadap merosotnya daya beli masyarakat Nasikh (2009). Usaha berskala kecil di Indonesia sendiri memberikan dampak positif bagi dunia bisnis, usaha berskala kecil akan terus berkembang seiring dengan perkembangan teknologi sehingga para pebisnis harus mulai memikirkan strategi-strategi dalam menghadapi persaingan terutama dalam cara mengkomunikasikan suatu produk kepada para pelanggan.

Perkembangan usaha berskala kecil di Indonesia umumnya masih menggunakan komunikasi pemasaran yang sederhana melalui komunikasi pemasaran word of mouth. Menurut hasil survei Bappenas(2003) terhadap UKM di Jawa, strategi dari mulut ke mulut merupakan alat promosi yang jitu atau banyak diandalkan komunitas bisnis setempat. Seperti halnya di Jawa Timur, 91\% UKM tersebut mengandalkan propaganda dari mulut ke mulut. (zahiraccounting.com, 12 Oktober 2010). Strategi komunikasi dari mulut ke mulut dalam dunia bisnis merupakan alat promosi yang handal terutama dalam menghadapi persaingan yang sangat ketat. Bagi usaha berskala kecil sendiri komunikasi wom merupakan komunikasi yang cukup efektif dan terbukti lebih kuat daripada promosi-promosi seperti iklan dan sebagainya. Hal ini terbukti WOM mempunyai pengaruh yang kuat dalam mempengaruhi, membujuk serta merekomendasikan hal-hal positif mengenai suatu produk yang di promosikan 
Usaha kecil yang menggunakan konsep komunikasi pemasaran salah satunya usaha Mie Ayam Pak Agus di Kota Batu yang berlokasi di Jalan Lesti No 17 Kota Batu, usaha ini didirikan olek bapak Agus sejak tahun 2000 dengan karyawan 7 orang. Mie ayam milik Pak Agus yang memiliki cita rasa yang halus dan nikmat, selain itu mie ayam Pak agus banyak di minati oleh semua segmen masyarakat dari berbagai kalangan baik itu mahasiswa, kantor pemerintahan setempat sekitaran kota Batu, masyarakat sekitar dan sebagaianya. Mie ayam milik Pak Agus merupakan salah satu dari berbagai mie ayam yang ada di kota MalangBatu seperti Mie Setan, Mie Hijau, Mie Hot, Miejogja, dan sebagainya. Begitu banyak produk mie ayam di kota Batu membuat para usaha kecil di bidang mie ayam harus berfikir keras dalam menentukan strategi yang jitu dalam menghadapi persaingan yang sangat ketat.

Munculnya mie ayam Pak Agus di Kota Batu banyak menyerap konsumen yang menggemari mie ayam. Banyaknya konsumen yang berdatangan dari berbagai lokasi di kota Batu hingga Malang membuat mie ayam Pak Agus terkenal hingga ke berbagai lokasi di Kota Batu hingga Kota Malang. Perkembangan usaha mie ayam PakAgus di Kota Batu dari tahun ke tahun mengalami peningkatan hal ini dilihat dari konsumen yang terus berdatangan serta melakukan pembelian berulang dan adanya rekomendasi dari seseorang yang menceritakan informasi menegenai produk mie ayam Pak Agus kepada orang lain, sehingga timbulnya minat beli pada konsumen setelah mendapatkan informasi mengenai produk mie ayam Pak Agus di Kota Batu. Produk mie ayam Pak Agus mendapatkan respon sangat positif dari konsumen sehingga konsumen tidak meragukan mengenai produk mie ayam Pak Agus, selain itu konsumen akan merasa puas setelah melakukan keputusan pembelian pada produk mie ayam PakAgus, hal ini di karenakan informasi yang di terima konsumen dari orang lain bersifat positif dan sesuai dengan informasi yang diterima.

Melihat semakin pesatnya informasi mengenai produk mie ayam Pak Agus tersebut, diduga adanya suatu komunikasi pemasaran dalam usaha mie ayam PakAgus terlihat dari informasi melalui mulut ke mulut mengenai produk mie ayam. Komunikasi dari mulut ke mulut ini tentunnya sangat bermanfaat bagi usaha yang dijalankan Pak agus, selain itu komunikasi dari mulut ke mulut ini sangat efektif dalam mempromosikan produk mie ayam Pak Agus karena komunikasi seperti ini tidak banyak mengeluarkan banyak biaya. Komunikasi dari mulut ke mulutmampumanjadimedia promosi yang jitu terhadap usaha PakAgus, informasi yang timbul dari suatu pembicaraan seseorang akan lebih dipercaya daripada media iklan seperti radio, banner, maupun media informasi lainya.

Fenomena tersebut terjadi karena adanya penyampaian pesan yang positifmengenai produk mie ayam tersebut, melihat hal-hal mengenai komunikasi word of mouth, suatu usaha harus memperhatikan pengaruh-pengaruh apa saja yang menimbulkan seseorang untuk melakukan minat pembelian pada produk mie ayam Pak Agus tersebut. Persepsi mengenai produk dan promosi melalui Word of Mouth Communication merupakan faktor yang dapat menstimuli keputusan pembelian dengan cara meningkatkan atau menawarkan produk sesuai apa yang diharapkan konsumen. Rumusan masalah dari penelitian ini adalah apakah WOM berpengaruh terhadap keputusan pembelian konsumen pada produk mie ayam Pak Agusdi Kota Batu, sedangkan tujuan dari penelitian ini adalah untuk mengetahui pengaruh komunikasi WOM terhadap keputusan pembelian konsumen pada produk mie ayam Pak Agus di Kota Batu. Diharapkan penelitian ini akan mem memberikan manfaat bagi pebisnis, yakni komunikasi wom mampu dijadikan suatu alat promosi yang jitu bagi suatu usaha berskala kecil, dengan wom para pebisnis dapat menghemat biaya periklanan yang cenderung lebih mahal dan kurang efektif dalam penyampaian suatu informasi mengenai produk yang di tawarkan kepada konsumen, yang kedua bagi teoritis adalah menambah wawasan ilmu pengetahuan dan memahami tentang dunia periklanan dan promosi secara efisien, serta diharapkan dapat dijadikan sebagai acuan bagi peneliti berikutnya yang berkaitan dengan pengaruh words of mouth terhadap keputusan. 


\section{TINJAUAN PUSTAKA}

Hasil penelitian Sari (2012) dengan judul "Analisis Pengaruh KualitasProduk, Persepsi Harga, Dan Word Of Mouth Communication Terhadap Keputusan Pembelian Mebel Pada CV. Mega Jaya Mebel Semarang”. Pada penelitian ini bertujuan untuk mengetahui pengaruh kualitas produk,persepsi harga, dan word of mouth communication terhadap keputusan pembelianmebel pada CV. Mega Jaya Mebel Semarang. Dimana variabel independen yaitukualitas produk, persepsi harga, dan word of mouth communication mempengaruhi keputusan pembelian sebagai variabel dependennya.

Pada pengujian asumsi klasik, model regresi bebas multikolinearitas, tidak terjadi heteros kedastisitas, dan berdistribusi normal. Secara individual, variabel yang memiliki pengaruh yang lebih besar adalah variabel Persepsi harga dengan koefisien regresi sebesar 0,347 , kemudian diikuti dengan variabel Word of Mouth Communication dengan koefisien regresi sebesar 0,306 dan yang memilikipengaruh paling kecil adalah kualitas produk dengan koefisien regresi sebesar 0,226. Pengujian hipotesis menunjukkan bahwa ketiga variabel independen yang diteliti terbukti secara signifikan mempengaruhi variabel dependen keputusan pembelian. Berdasarkan analisis regresi oleh SPSS, variabel keputusan pembelian dapat dijelaskan oleh variabel kualitas produk,persepsi harga dan Word of Moutrh Communication sebesar $50,5 \%$, sedangkan sisanya sebesar $49,5 \%$ dijelaskan oleh variabel lain di luar ketiga variabel yang digunakan dalam penelitian ini.

Praswati (2009) melakukan penelitian judul penelitian “Analisis Faktor-Faktor Yang Mempengaruhi Komunikasi Word OfMouth Terhadap Minat Guna Jasa Ulang (Studi Kasus Pada PT. Nasmoco diSemarang) “.Penelitian ini menganalisis faktor-faktor yang mempengaruhi komunikasi word ofmoth terhadap minat guna jasa ulang. Obyek penelitian ini adalah PT. Nasmoco di Semarang. Permasalahan penelitian merujuk pada fenomena bisnis PT. Nasmoco diSemarang. Oleh karenanya permasalahan penelitian ini adalah sebagai berikut:bagaimana meningkatkan minat guna jasa ulang melalui komunikasi word of mouth.Sebuah permodelan telah dibangun dan lima hipotesis penelitian telah dirumuskan.

Metode purposif telah dipilih untuk memperoleh data yang dibutuhkan pada studiini. Penelitian ini mempergunakan 145 responden dan keseluruhan responden adalahpelanggan PT. Nasmoco di Semarang. Analisis data mempergunakan Structural EquationModel dengan program komputer Amos 16. Model penelitian ini telah memenuhi kriteriaGoodness of Fit yaitu chi square $=(253,724)$; probability $=(0,054) ; \mathrm{GFI}=(0,871)$; AGFI $=(0,838)$; $\mathrm{CFI}=(0,983)$; $\mathrm{TLI}=(0,980)$; RMSEA $=(0,033) ; \mathrm{CMIN} / \mathrm{DF}=(1,159)$. Hasil penelitian ini menunjukkan diantaranya bahwa kualitas pelayananberpengaruh positif terhadap komunikasi wom. Kepuasan pelanggan berpengaruh positifterhadap komunikasi wom. Komitmen berpengaruh positif terhadap komitmen wom. Kekuatan hubungan berpengaruh positif terhadap komunikasi wom. Komunikasi womberpengaruh postif terhadap minat guna jasa ulang.

Komunikasi pemasaran merupakan proses yang dilakukan oleh perusahaan dalam mengkoordinasikan beberapa elemen promosi dan kegiatan pemasaran lainnya sehingga terjalin komunikasi dengan konsumen perusahaan (Belch \& Belch, 2004). Dengan menggunakan marketing communication tools yang tepat, perusahaan selaku komunikator dapat memperkenalkan serta memasarkan barang atau jasanya kepada konsumen selaku komunikan. Berikut bentuk-bentuk utama dari komunikasi pemasaran, pertama Penjualan perorangan (personal selling) adalah bentuk komunikasi antar individu di mana tenaga penjual/wiraniaga menginformasikan, mendidik,dan melakukan persuasi kepada calon pembeli untuk membeli produk atau jasa perusahaan, kedua Iklan (advertising) suatu bentuk komunikasi non personal mengenai suatu organisasi atau perusahaan, produk, jasa, maupun gagasan yang telah dibayar oleh sponsor tertentu. Dianggap non personal karena disebarkan melalui media massa dalam skala besar dan dalam satu waktu yang bersamaan, serta kurang memungkinkan untuk dapat direspon langsung oleh konsumen, tiga Promosi penjualan (sales promotion) 
terdiri dari semua kegiatan pemasaran yang mencoba merangsang terjadinya aksi pembelian suatu produk yang cepat atau terjadinya pembelian dalam waktu yang singkat. Sebagai bahan perbandingan, ada iklan yang di desain untuk mencapai tujuan lain yaitu menciptakan kesadaran pada merek dan mempengaruhi sikap pelanggan. promosi penjualan diarahkan baik untuk perdagangan (kepada pedagang besar dan pengecer) maupun kepada konsumen. Promosi penjualan yang berorentasi perdagangan memberikan berbagai jenis bonus untuk meningkatkan respon dari pedagang besar dan pengecer, empat adalah Pemasaran sponsorsip adalah aplikasi dalam mempromosikan perusahaan dan merek mereka dengan menegoisasikan perusahaan atau salah satu dari merek dengan kegiatan tertentu, kelima Publishitas (publicity), seperti halnya iklan, publisitas menggambarkan komunikasi massa; namun juga tidak seperti iklan, perusahaan sponsor tidak mengeluarkan biaya untuk waktu dan ruang beriklan. Publisitas biasa di lakukan dalam bentuk berita atau komentar editorial mengenai produk atau jasa dari perusahaan. Bentuk-bentuk penting ini di muat dalam media cetak atau televisi secara gratis karena terwakilan media menganggap informasi tersebut penting dan layak di sampaikan kepada khalayak mereka, terakhir yaitu Komunikasi di tempat pembelian(point of-purchase communication) melibatkan peraga, poster, tanda, dan berbagai materi lain yang di desain untuk mermpengaruhi keputusan untuk membeli dalam tempat pembelian.

Menurut Onong (2001) Istilah komunikasi berasal dari kala Latin, yaitu commimicalio, yang bersumber dari communis yang berarti sama. Misalkan, jika dua orang bercakap-cakap, maka percakapan tersebut dikatakan komunikatif jika keduanya, selain mengerti bahasa yang digunakan, juga mengerti makna dari bahan yang dipercakapkan, komunikasi yang komunikatif sangat dibutuhkan dalam membangun suatu relasi yang baik antar individu dalam keluarga dan masyarakat. Demikian halnya dalam setiap organisasi, bahwa komunikasi merupakan hal yang amat penting sebagai sarana efektif dalam memajukan dan mengembangkan organisasi yang bersangkutan. Di sini, komunikasi organisasi mencakup informasi yang disalurkan secara formal dari atasan kepada bawahan (downward communication) dari bawahan kepada atasan (upward communication), antara teman kerja (horizontal communication) atau di antara para atasan maupun di antara bawahan dalam unit yang berbeda dalam suatu organisasi (cross channel communication).

Menurut Word of mouth Marketing Association pengertian dari word of mouth adalah usaha meneruskan informasi dari satu konsumen ke konsumen lain (www.womma.com, 2007). Di dalam masyarakat word of mouth dikenal juga dengan istilah komunikasi dari mulut ke mulut. Komunikasi personal ini dipandang sebagai sumber yang lebih dapat dipercaya atau dapat diandalkan dibandingkan dengan informasi dari nonpersonal (Gremler dan Brown, 1994; Zeithml dan Bitner, 1996).

Penelitian tentang WOM dua kali lebih efektif dalam mempengaruhi pembelian dibandingkan dengan iklan radio, empat kali di bandingkan dengan penjualan pribadi dan tujuh kali di bandingkan dengan iklan di majalah dan koran (Assael, 1992). Kepemilikan sesuatu dapat di kelompokan berdasarkan sisi jalur kanan atau kiri dan tidak menyebrang jalan. Dalam hal ini di simpulkan kepemilikan sesuatu berdasarkan sisi jalur jalan tertentu menunjukkan adanya pola kommunikasi WOM antar tetangga seperti mengobrol di balik pagar, atau halaman belakang

Menurut Kotler (1998), menyatakan bahwa WOM adalah pengaruh personal, yang berkaitan erat dengan produk yang mahal dan penuh resiko. Harapan kemungkinan resiko yang akan diterima berkurang dengan bertanya atau meminta rekomendasi dari teman (Heskett, et al 1997). (Lovelock, 2001), juga menekankan bahwa WOM sebagai pendapat dan rekomendasi yang dibuat oleh konsumen tentang pengalaman servis, yang mempunyai pengaruh kuat terhadap keputusan konsumen atau perilaku pembelian. Hal ini menunjukkan bahwa orang lebih percaya terhadap informasi dari teman dibandingkan iklan ataupun tenaga penjual. 
Definisi secara sederhana Word of Mouth atau WOM adalah tindakan penyedia informasi apapun terkait produk oleh konsumen kepada konsumen lain. WOM menurut WOMMA (Word of Mouth Marketing Assoctation) adalah suatu aktifitas di mana konsumen memberikan informasi mengenai suatu merek atauproduk kepada konsumen lain. Dan Word of Mouth Marketing adalah kegiatanpemasaran yang memicu konsumen untuk membicarakan, mempromosikan, merekomendasikan hingga menjual merek suatu produk kepada calon konsumenlainnya (Sumardy, 2011). Berkaitan dengan komunikasi yang ada pada suatu organisasi, menurut (Hoskins,2007) dilihat dari sifatnya salah satunya adalah komunikasi word of mouth communication atau komunikasi mulut ke mulut. Menurutnya, komunikasi ini dibutuhkan untuk kepentingan internal dan eksternal organisasi. Komunikasi untuk kepentingan internal adalah sebagai alat koordinasi, mengontrol, setiap kegiatan atau aktivitas dalam organisasi baik individu maupun secara komunal (bersama) di tingkat manajemen dan di level staf atau karyawan. Di sini, organisasi menurut (Hoskins,2007) berfungsi sebagai wadah interaksi secara langsung yang mensyaratkan komunikasi word of mouth yakni adanya bentuk kerjasama antara dua orang atau lebih dalam mencapai tujuan yang hendak dicapai bersama. Hal ini memperlihatkan bahwa setiap aktivitas yang terjadi dalam organisasi merupakan interaksi antar anggota organisasi secara langsung yang salah satunya melalui komunikasi word of mouth. Dengan komunikasi tersebut, suatu organisasi menjadi hidup dan berkembang secara dinamis. Organisasi tanpa suatu komunikasi, akan mengakibatkan segala aktivitas akan terhenti.

Sementara, komunikasi word of mouth untuk kepentingan eksternal menurut Hoskins(2007) bertujuan untuk menjalin relasi dengan organisasi lain atau pihak-pihak yang berkepentingan. Suatu organisasi penting menjalin hubungan dengan organisasi di luar dirinya. Dalam usaha menjalin kerjasama tersebut, komunikasi melalui word of mouth akan menjadi lebih efektifuntuk menjalin ikatan yang baik dengan pihak organisasi Iain karena akan dapat membangun ikatan emosionalyang kuat. Berdasarkan (Sernovitz, 2006), word of mouth terdiri dari 2 yaitu Organic word of mouth adalah pembicara yang bersemi secara alami dari kualitas positif dari perusahaan anda dan Amplifeld word of mouth adalah pembicaraan yang di mulai oleh kampanye yang disengajakan untuk membuat orangorang berbicara. Menurut (Silverman, 2001), word of mouth begitu kuat karena hal-hal berikut yang pertama adalah kepercayaan yang bersifat mandiri, kedua adalah penyampaian pengalaman. Ketika seseorang ingin membeli suatu produk, orang tersebut akan mencapai suatu titik dimana dia ingin mencoba produk tersebut. Secara idealnya dia ingin mendapat resiko yang rendah, pengalaman dunia nyata dalam menggunakan produk. Dengan kata lain, dia membutuhkan pengalaman. Suatu perasaan yang sangat puas terjadi karena konsumen merasa puas dengan apa yang ia harapkan, dimana orang yang merasa sangat puas akan memberikan suatu effects seperti pembelian berulang dan penyebaran positif word of mouth kepada konsumen lainya.

Beberapa faktor dapat dijadikan dasar motifasi bagi konsumen untuk membicararakan mengenai produk. Pertama, seseorang mungkin begitu terlibat dengan suatu produk tertentu atau aktifitas tertentu dan bermaksud membicarakan mengenai hal itu dengan orang lain, sehingga terjadi proses komunikasi WOM. Misalnya para penjelajah internet akan senang membicarakan pengalamannya menjelajah belahan dunia luar kepada orang yang juga bermaksud menjelajah dunia lewat internet. Kedua, seseorang mungkin banyak mengetahui mengenai produk dan menggunakan percakapan sebagai cara untuk menginformasikan kepada orang lain. Dalam hal ini WOM dapat menjadi alat untuk menanamkan kesan kepada orang lain bahwa kita mempunyai pengetahuan atau keahlian tertentu. Ketiga, seseorang mungkin mengawali suatu diskusi dengan membicarakan sesuatu yang keluar dari perhatian utama diskusi. Dalam halini mungkin saja karena ada dorongan dan keinginan bahwa orang lain tidak boleh salah dalam memilih barang dan jangan menghabiskan waktu untuk mencari informasi mengenai suatu merek 
produk. Keempat, WOM merupakan satu cara untuk mengurangi ketidakpastian, karena dengan bertanya kepada teman, keluarga atau tetangga, informasinya lebih cepat di percaya, sehingga juga akan mengurangi waktu penulusuran dan evaluasi merek.(Sutisna, 2002).

Menurut Sernovitz(2006), definisi WOM marketing adalah tindakan yang dapat memberikan alasan supaya semua orang lebih muda dan suka membicarakan produk anda, ada 4 hal agar orang lain membicara produk atau jasa dalam word of mouth marketing yaitu Be interesting, Make people happy, Earn Trust and Request, Make it easy. Kemudian ada 3 alasan atau motivasi orang mau membicarakan produk atau perusahaan anda (Sernovitz, 2006) yakni They like you and your stuff, Taking makes them feel good, dan They Feel connected to the group. Pelanggan tetap maupun baru yang berpengalaman tentang pelayanan suatu perusahaan akan mulai berinteraksi dengan pelanggan yang lain. Penilaian akan terjadi pada tahap penilaian di mana pelanggan akan memutuskan untuk kembali atau tidak. Tanggapan positifatau negatifakan mempengaruhi apakah pelanggan lain akan menggunakan pelayanan yang di berikan. Komunikasi dari mulut ke mulut akan menyebabkan efek ganda dari suatu perusahaan ke perusahaan yang lain dan dari satu situasi ke situasi yang lain. Bagaimanapun juga tanggapan yang negatif akan mengakibatkan efek yang lebih hebat daripada tanggapan yang positif. Pelanggan yang tidak puas akan menyampaikan ketidakpuasan dua kali dariapada pelanggan yang puas. Efek negatif dari ketidakpuasan pelanggan akan menentukan kelangsungan dari suatu prusahaan, sementara efek positif dari kepuasan pelanggan berakibat lebih kecil terhadap kelangsungan perusahaan.

Word of mouth memiliki pengaruh yang kuat pada persepsi produk dan jasa, yang menyebabkan perubahan penilaian, peringkat nilai, dan kemungkinanpembelian. Penelitian menemukan bahwa WOM lebih penting di tahap proses pembelian seperti meyakinkan konsumen dan mengurangi ketidakpastian pasca pembelian (Sweeney, et al.dkk, 2007).
Proses pengambilan keputusan merupakan seragkaian aktivitas mental dan fisik yang di lakukan oleh konsumen sebelum terjadi pembelian aktual (ferrinadewi dan darmawan, 2004,), setiap konsumen melakukan berbagai macam keputusan tentang pencarian, pembelian, penggunaan beragam produk, dan merek pada setiap periode tertentu. Berbagai macam keputusan mengenai aktifitas kebutuhan seringkali harus di lakukan oleh konsumen pada setiap hari. Konsumen melakukan keputusan setiap hari tanpa menyadari bahwa mereka telah mengambil keputusan. Disiplin perilaku konsumen dan memahami faktor-faktor apa saja yang mempengaruhi dan yang terlibat dalam pengambilan keputusan tersebut. Schiffman dan Kanuk (2004) mendefinisikan suatu keputusan sebagai pemilihan suatu tindakan dari dua atau lebih pilihan alternatif, seseorang konsumen yang hendak melakukan pilihan maka ia harus memiliki pilhan alternatif.

WOM menjadi bagian penting dalam studi pemasaran mengingat bahwa komunikasi dalam WOM mampu mempengaruhi keputusan pembelian konsumen. Di sisi lain, kekuatan WOM juga bertambah mengingat bahwa manusia adalah makhluk sosial yang senang berinteraksi dan berbagi dengan sesamanya, termasuk masalah preferensi pembelian. WOM mampu menyebar begitu cepat bila individu yang menyebarkannya juga memiliki jaringan yang luas. WOM adalah suatu sarana komunikasi pemasaran yang efektif, murah, dan kredibel (Kertajaya, 2007)

Konsumen lebih mempercayai Word of Mouth dalam menilai sebuah produk, dan mempengaruhi keputusan pembelian mereka dibandingkan iklan.Cerita dan pengalaman seseorang menggunakan sebuah produk terdengar lebih menarik yang bisa mempengaruhi pendengarnya untuk ikut mencoba produk tersebut. Kita seperti tidak pernah merasa bosan mendengarkan cerita dari teman ataupun anggota keluarga tentang pengalamannya menggunakan sebuah produk atau jasa.

Seperti yang sudah dijelaskan sebelumnya $67 \%$ keputusan pembelian dipengaruhi oleh rekomendasi dari teman atau keluarga, yang berarti di sini rekomendasi mempunyai kekuatan pengaruh 
yang sangat besar pada keputusan pembelian seseorang terhadap suatu produk. Sumardy(2011) Menyatakan Tidak peduli perusahaan kecil atau besar, WOM tetap menjadi praktik pemasaran yang palingmendominasi keputusan pembelian konsumen terhadap produk apapun. Suatu penelitian yang dilakukan oleh Haryono dkk.(2003) yang memasukan Word of Mouth sebagai salah satu variabel dalam penelitiannya menunjukan bahwa rekomendasi personal dari mulut ke mulut (word of mouth)berpengaruh positif dan signifikan terhadap keputusan pembelian. Strategi word of mouth berkaitan erat dengan reference groups. Kelompok yang dijadikan sumber referensi oleh konsumen ini tediri dari teman-teman, tetangga, perkumpulan, dan keluarga. Dalam memutuskan membeli, konsumen biasanya mengandalkan opini dari kelompok referensi daripada informasi dari iklan atau tenaga penjual. Rosen(2000), menyatakan bahwa enam unsur yang harus dimiliki suatu produk untuk bisa menghasilkan word-of-mouth secara positif dan terus menerus artinya produk tersebut mampu membangkitkan tanggapan emosional, mampu memberikan sesuatu yang melebihi dari ekspetasi konsumen, mempunyai sesuatu yang dapat mengiklankan dirinya sendiri atau memberikan inspirasi seseorang untuk menanyakan hal tersebut, produk menjadi lebih powefull bila penggunanya banyak, kompatibel dengan produk lainnya, khususnya dapat diaplikasikan di produk yang mengandalkan teknologi, dan pengalaman konsumen menggunakan produk pertama kali. Sekali konsumen kecewa, mereka tidak akan menggunakan produk anda lagi dan mereka akan bertindak seperti teroris.

Pernyataan terakhir didukung oleh Dharmestha (2007), bahwa konsumen yang tidak puas adalah iklan terburuk perusahaan. Metode menciptakan word of mouth berdasarkan penelitian Diamond Management \& Technology Consultant (2007), terdapat beberapa bentuk word-of-mouth pada antara lain Buzz marketing, Evangelist marketing, Community marketing, Conversation creation, Influencer marketing, Cause marketing, Viral marketing, Grassroots marketing, Brand blogging, Product seeding, serta
Referral programs. Sedangkan implikasi wordof-mouth terhadap para pemasar antara lain mereka akan terfokus kepada kepuasan pelanggan. Pendapat Iput (2007), ketika seorang konsumen mengeluarkan uang untuk mengkonsumsi suatu produk atau jasa, ia secara langsung juga mengkonsumsi sebuah experience, yang kemudian memberi efek persepsi, dan berakhir pada suatu tingkat kepuasan emosional. Kepuasan emosional inilah yang akan menghasilkan sebuah word-ofmouth, yang mungkin sering muncul tanpa sengaja, namun sebenarnya bisa direncanakan dengan strategi yang tepat, dengan goal yang diinginkan perusahaan. Berdasarkan keadaan tersebut, dalam rangka menciptakan word-of-mouth yang positif, penting untuk diperhatikan adalah Konsumen yang terpuaskan (harapannya akan produk/jasa itu terpenuhi), belum tentu $100 \%$ akan menceritakannya kepada orang lain, Word-of-mouth positif akan muncul dari suatu experience yang dianggap luar biasa oleh seorang konsumen, yang pada saat itu tingkat kepuasan emosionalnya tinggi. Kepuasan ini di Hospitality Management disebut emotional satisfaction. Kepuasan yang muncul karena emosi, terhadap kualitas. Baik dari sebuah produk/ jasa, ditambah dengan kualitas experience yang juga dibeli oleh konsumen, Word-of-mouth negatif adalah suatu fenomena yang paling ditakutkan perusahaan atau pengusaha. Karena seorang konsumen yang tingkat kepuasaan, terutama emosionalnya negatif, akan berbicara, bukan hanya ke orang-orang dekatnya saja. Ketidakpuasan belum tentu dari fisik sebuah produk atau jasa, tapi bisa intangible seperti mungkin dari fasilitas, pelayanan dan pengalamannya ketika melakukan purchase.

Siverman(2001) berpendapat bahwa komunikasi word of mouth(WOM) merupakan komunikasi interpersonal yang terjadi antara individu satu dengan individu yang lain berdasarkan pada pengalaman yang dimiliki oleh masing-masing individu terhadap suatu perusahaan atau produk baik yang berupa barang maupun jasa. Mendukung pendapat Siverman \& Hughes (2005) mengemukakan hal yang sama bahwa komunikasi word of mouth (WOM) merupakan komunikasi interpersonal yang efektif dalam mempengaruhi sikap seseorang 
seperti dalam menyampaikan informasi seputar produk atau jasa seperti yang terkandung dalam definisi komunikasi word of mouth berikut ini: "Communication about products and service" between people who are perceived to he independent of the company providing the product or services, $m$ a medium perceived to be independent of the conipanv".

Berdasarkan pada rumusan masalah dan telaah pustakayang telah diuraikan dimukamengenai variabel komunikasi dari mulut ke mulut (word of mouth communication) serta pengaruhnya terhadap keputusan pembelian, maka kerangka pemikiran teoritis yang diajukan adalah sebagai berikut:

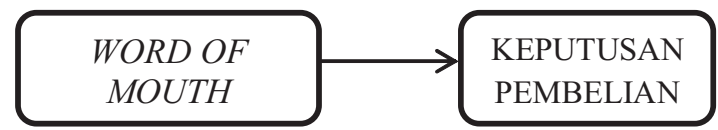

Gambar 2.4 kerangka penelitian

Hipotesis dalam penelitian ini adalah komunikasi dari mulut ke mulut (Word of Mouth Communication)berpengaruh positif terhadap keputusan pembelian.

\section{METODOLOGI PENELITIAN}

Berdasarkan jenis masalah yang diteliti, dan tujuan yang ingin dicapai, maka penelitian ini jika dilihat dari segi metode yaitu menggunakan penelitian survey. (Sugiyono, 2003) mengemukakan bahwa penelitian survey adalah penelitian yang dilakukan pada populasi besar maupun kecil, tetapi data yang dipelajari adalah data dari sampel yang diambil dari populasi tersebut,bukan dari data dukung lainnya, sehingga ditemukan kejadian - kejadian relatif, distribusi, dan hubungan - hubungan antar variabel sosiologis maupun psikologis. Penilitian ini menggunakan dua variabel. Variable dependen $(\mathrm{Y})$ dan variable independen $(\mathrm{X})$, dimana variable dependen adalah Keputusan Pembelian $(\mathrm{Y})$, sedanglan variable independen adalah komunikasi dari mulut ke mulut (Word of Mouth Communication).

Word of Mouth Communication merupakan kegiatan yang memicu konsumen untuk mem- bicarakan, mempromosikan, merekomendasikan hingga menjual Produk Mie Ayam Pak Agus kepada calon konsumenlainnya.(Praswati, 2009) dengan indikator satu menceritakan hal-hal positif, dua mengajak dan membujuk konsumen lain, ketiga adalah merekomendasikan kepada orang lain. Sedangkan konsumen akan melakukan keputusan pembelian pada produk Mie Ayam Pak Agus apabila semua yang diharapkan oleh konsumen dapat di penuhi seperti kualitas produk, persepsi harga serta, kesesuaian produk dengan apa yang telah di sampaikan oleh konsumen kepada calon konsumen lain melalui Word of Mouth Communication. Sehingga, indikator yang digunakan dalam penelitian ini adalah satu keinginan yang timbul dari afektif seseorang untuk melakukan pembelian terhadap produk Mie Ayam Pak Agus yang muncul karena adanya rekomendasi dari seseorang mengenai produk Mie Ayam Pak Agus di Kota Batu, kedua pembelian berulang, pembelian yang di lakukan konsumen lebih dari 1 kali membeli dan merekomendasikan kepada kerabar dekat, ketiga keputusan membeli dilihat dari mutu produk yang dianggap memiliki cita rasa dan kualitas mengenai produk Mie Ayam Pak Agus di Kota Batu, keempat adalah harapan rasa puas konsumen setelah melakukan pembelian dari produk Mie Ayam Pak Agus di Kota Batu.

Populasi dalam penelitian adalah konsumen yang melakukan pembelian berulang di mie ayam pak Agus minimal tiga kali. Menurut (Widayat, 2004) menyarankan, besar sampel minimum untuk penelitian deskriptif sebanyak 100, penelitian korelasional sebanyak 50, penelitian kausal perbandingan 30/grup. Maka sampel yang diambil adalah sebanyak 100 responden. Sedangkan yang menjadi responden adalah konsumen yang melakukan pembelian pada Usaha Mie Ayam PakAgus di Kota Batu. Instrumen penelitian adalah alat yang digunakan untuk mengukur fenomena alam maupun sosial yang diamati (Sugiyono, 2000). Dalam penelitian ini teknik pengumpulan data menggunakan kuesioner. Menggunakan koesioner untuk mengungkap variabel-variabel yang mempengaruhi kinerja pengukuran menggunakan skala interval berdasarkan skala likert yaitu skor yang digunakan 
satu sampai lima yang diterapkan secara bervariasi menurut masing-masing kategori pertanyaan. Kemudian dianalisis menggunakan SPSS for windows dengan alat regresi linear sederhana.

\section{HASIL PENELITIAN DAN PEMBAHASAN}

Dari hasil analisis regresi linier sederhana dengan program SPSS dapat diperoleh hasil tentang R Square, koefisienregresi, dan t-hitung. Hasil analisis regresi linier sederhana dapat ditunjukkan sepertipada Tabel 1 berikut:

Dari hasil perhitungan analisi regresi linier sederhana yang telah dilakukan menunjukkan pengaruh variabel independent terhadap variabel dependent adalah sebesar, hal tersebut dapat dilihat padanilai koefisien determinasi $\left(\mathrm{R}^{2}\right)$ yaitu 0,772 . Dengan demikian berarti bahwa pengaruh WOM Terhadap Keputusan Pembelian Pada Usaha Mie Ayam Pak Agus Di Kota Batu sebesar $77,2 \%$, sedangkan sisanya sebesar $22,8 \%$ dijelaskan oleh variabel-variabel lain yang tidak termasuk dalam penelitian ini.

Koefisien korelasi sederhana $\mathrm{R}$ (multiple Correlation) menggambarkan kuatnya hubungan antara variabel independent yang meliputi variabel WOM secara bersama-sama terhadap variabel dependent yaitu keputusan pembelian pada usaha mie ayam Pak Agus Di Kota Batu (Y) adalah sebesar 0,879 . Hal ini berarti hubungan antara keseluruhan variabel adalah sangat erat karena nilai R tersebut mendekati 1 .

Besarnya koefisien variabel dimensi kualitas pelayanan meliputi WOM mempunyai pengaruh signifikan terhadap Keputusan Pembelian
Konsumen Pada Usaha Mie Ayam Pak Agus di Kota Batu. Uji hipotesis menyatakan bahwa "ada pengaruh WOM terhadap keputusan pembelian konsumen Pada Usaha Mie Ayam Pak Agus Di Kota Batu “. Hasil yang diperoleh dari uji hipotesis dengan teknik analisis regresi sederhana menunjukkan adanya pengaruh word of mouth terhadap keputusan pembelian konsumen pada usaha mie ayam Pak Agus di Kota Batu. Hasil penelitian ini sesuai dengan hipotesis yang diajukan bahwa terdapat pengaruh WOM terhadap keputusan pembelian konsumen pada usaha mie ayam Pak Agus di Kota Batu. Hasil penelitian membuktikan bahwa faktor yang berpengaruh terhadap keputusan pembelian pada usaha Mie Ayam Pak Agus di Kota Batu adalah adanya pengaruh WOM yang dilakukan konsumen.

\section{SIMPULAN}

Berdasarkan penelitian tentang pengaruh WOM terhadap keputusan Pembelian pada Usaha Mie Ayam Pak Agus di Kota Batu, maka diperoleh kesimpulan sebagai berikut yang pertama dari hasil regresi linear berganda dan uji parsial menunjukkan bahwa adanya Pengaruh WOM Terhadap Keputusan Pembelian Konsumen Pada Usaha Mie Ayam Pak Agus di Kota Batu, pada nilai r square sebesar 0,772 atau 77,2\% membuktikan bahwa variabel WOM mempunyai pengaruh positif dan memiliki pengaruh yang kuat terhadap keputusan pembelian. Maka dari itu, adapun saran dari penelitian ini adalah yang pertama bagi Usaha Mie Ayam PakAgus perlu meningkatkan kualitas produk mie ayam. Karena kualitas produk yang baik akan menimbulkan kepuasan pelanggan sehingga mendo-

Tabel 1: Hasil Analisis Regresi Sederhana

\begin{tabular}{lcccc}
\hline \multicolumn{1}{c}{ Variabel } & $\begin{array}{c}\text { Koefisien } \\
\text { Regresi }\end{array}$ & Standart error & t hitung & Sig \\
\hline \multicolumn{1}{|}{$\mathrm{X} 1$} & 1,702 & 0,093 & 18,224 & 0,000 \\
$\begin{array}{l}\text { Constanta: } 4,382 \\
\text { Koefisien determinasi }\left(\mathrm{R}^{2}\right): 0,772\end{array}$ & & & \\
$\begin{array}{l}\text { Multiple Correlation }(\mathrm{R}): 0,879 \\
\text { Fhitung }=332.101\end{array}$ & & & \\
$\alpha=5 \%$ & & & \\
\hline
\end{tabular}


rong untuk melakukan pembelian berulang dan kemudian menimbulkan loyalitas dan meningkatkan tingkat penjualan pada usaha mie ayam Pak Agus di Kota Batu, kedua adalah rekomendasi. Perbincangan hal-hal positif mengenai produk mie ayam Pak Agus sangat di perlukan bagi usah mie ayam Pak Agus, hal ini bertujuan agar konsumen selalu merekomendasikan, mempengaruhi, dan membujuk rekan, kerabat, teman, keluarga agar mencoba produk mie ayam Pak Agus. Ketiga yaitu, tingkat kepercayaan dan kepuasan pada pelanggan dapat meningkatkan loyalitaspelanggan dalam melakukan pembelian pada produk mie ayam Pak Agus. Hal ini dikarenakan kualitasm citra rasa, dan pelayanan di mata pelanggan telah mempunyai persepsi yang baik pada produk Mie Ayam Pak Agus dan mendorong mereka untuk melakukan pembelian ulang, keempat adalah peningkatan pada varian produk.

Selanjutnya adalah saran bagi peneliti selanjutnya, yakni melakukan penelitian lebih lanjut terhadap faktor-faktor selain komunikasi WOM yang berpengaruh terhadap keputusan pembelian konsumen pada usaha mie ayam Pak Agus di Kota Batu. Hal ini dikarenakan, dalam penelitian ini variabel WOM tersebut hanya mampu menjelaskan 53,2 persen dari keputusan pembelian. Untuk penelitian yang akan datang disarankan untuk membandingkan produk mie ayam dengan produk mie lainnya yang sejenis dengan pengaruh yang beda seperti loyalitas, maupun kepuasan konsumen akan suatu produk. Hal ini dapat dijadikan pembanding sekaligus melengkapi penelitian ini, kemudian mencari ruang lingkup populasi yang berbeda dan lebih luas dari populasi dalam penelitian ini, begitu juga dengan banyaknya jumlah sampel yang digunakan dengan demikian penelitian lanjutantersebut dapat semakin memberikan gambaran yang lebih spesifikmengenai pengaruh komunikasi WOM terhadap keputusan pembelian.

\section{DAFTAR PUSTAKA}

Belch, George E. 2004. Advertising and Promotion: An Integrated Marketing Communi- cations Perspective. Edisi ke-6. Mc GrawHill Company. New York.

Dharmestha, dan Irawan.2007. Manajemen Pemasaran Modern. Edisi Kedua. Liberty. Yogyakarta.

Effendy, Onong Uchjana. 2002. Ilmu Komunikasi, Teori dan Praktek. Bandung: Remaja rosda karya

Kertajaya, Hermawan. 2007. Hermawan Kertajaya on Marketing. PT Gramedia. Jakarta.

Kotler, Philip. 1998. Manajemen Pemasaran. Prenhallindo. Jakarta.

Lovelock, Christoper H. 2001. Services Marketing: People, Technology, Strategy. Fourth Edition. Prentice Hall. United States of America.

Praswati, Aflit N. 2009. Analisis Faktor-Faktor Yang Mempengaruhi Komunikasi Word Of Mouth Terhadap Minat Guna Jasa Ulang (Studi Kasus Pada PT. Nasmoco diSemarang). Skripsi

Sari, Ratna D.K. 2012. Analisis Pengaruh KualitasProduk, Persepsi Harga, Dan Word Of Mouth Communication Terhadap Keputusan Pembelian Mebel Pada CV. Mega Jaya Mebel Semarang. Skripsi

Schiffman, Leon G. And Leslie Kanuk. 2004. Consumer Behavior. Pearson prentice Hall. New Jersey.

Sernovitz, Andy. 2006. Word of Mouth Marketing (WOM). How smart Companies get people Talking. Kaplan.

Silverman, George. 2001. The Secret of Worsof-Mouth Marketing: How to Trigger Exponential Sales through Runaway Word-ofMouth. AMACOM(American Management Assosiation) Books. New York.

Sugiyono. 2008. Metode penelitian bisnis. CV Alfabeta. Bandung.

Sutisna. 2002. Perilaku Konsumen dan Komunikasi pemasaran; cetakan kedua. PT Remaja Rosdakarya,Bandung. 